\title{
The feasibility of reducing yield gap by improving crop management
}

\author{
H. Fateh ${ }^{1}$, A. Toube ${ }^{2}$, A.Q. Gholipuri ${ }^{2}$ \\ ${ }^{1}$ Department of Ecology, University of Mohagheghe Ardebili, Ardabil, Iran. \\ ${ }^{2}$ Department of Agronomy and Plant Breeding, University of Mohagheghe Ardabili, Ardabil, Iran. \\ E-mail: shams2243@gmail.com \\ Received: 12.06.2019. Accepted: 08.07.2019
}

\begin{abstract}
An appropriate solution to increase crop production is to improve production per unit area. Reconsiderations are, therefore, necessary in various agricultural systems and their production potential. To evaluate agronomic factors affecting crop yield and feasibility of reducing wheat yield gap, a questionnaire was developed in terms of yield-affecting management factors. For this purpose, data of most important factors affecting wheat yield were recorded from farmers sampled from different parts of Piranshahr, a southern city in West Azerbaijan province, Iran. The results showed that the management applied throughout the season had a significant effect on wheat yield. The lands with more than three hectares, flat, and northward with loam-clay soil texture yielded relatively higher crop. The yields were also higher in the lands plowed in March and August with a three-plough moldboard connected to a four-cylinder Ferguson tractor, flattened using a trowel, and rotated with fallow and pea. The use of phosphate (100-150 kg ha-1), potash, and micro fertilizers, as well as 100-150 kg of urea (50 kg in spring and $50 \mathrm{~kg}$ in autumn) led to increased yield. The use of Granstar (60 g) and $1.0 \mathrm{~L}$ of 2, 4-D separately, and $0.5 \mathrm{~L}$ of a pesticide resulted in a better seed yield. Harvesting of wheat in July 15-25 using Hyundai and 130k combines resulted in higher yields. The percentages of studied managements, including land characteristics, planting, growing, and harvesting in wheat fields were $13,35,27$, and 25 percent, respectively.
\end{abstract}

Keywords: Wheat; yield; crop management; fertilizer; Iran

\section{Introduction}

Agricultural operations are based on man's traditional knowledge and experience. The task of agricultural research is to promote technical knowledge and provide scientific background in order to boost the knowledge of researchers and experts in the agricultural sector and ultimately increase farmers' experience aiming at improving crop production (Ziaeian, 2003). In this regard, an appropriate solution is to increase yield per unit area in order to multiply agricultural production (Siosemardeh, 2003). In particular, excessive use of pesticides and fertilizers in Iran has caused severe damages to soil and water resources, reduced land strength, environmental pollution, damage to natural environmental cycles, and health problems for humans, livestock, and nature (Sharghi et al., 2010). Studies suggest that wheat farmers are not generally wellinformed about agriculture. Arabion et al. (2009) surveyed the sustainability of wheat cultivation systems in Fars province and concluded that $68.4 \%$ of farmers had sustainable and unsustainable wheat cultivation systems.

Various tillage systems include conservative tillage, minimum tillage, and conventional tillage during fallowing period in rainfed wheat lands in different parts of the world. These different methods result in a variety of yields. The main effects of these tillage methods are preserving residues on the soil surface, reducing runoff and soil erosion, increasing soil organic matter, maintaining soil moisture, mineralizing soil organic matter, and so on. According to reports in some parts of Iran, moldboard plow significantly increased rainfed wheat yield with no significant increase in water stored in the soil, which was attributed to good soil aeration, better mineralization of organic matter, and better seed bed preparation (Shahoei et al., 1989). In addition to the cultivar, weed control is also among management factors affecting wheat yield. It has been reported that chemical weed control in the middle of spring increased wheat yield by reduction weed competition, improving the relative growth rate, and increasing the ratio of wheat leaf area to total plant weight (Ahmadi and Jafarzadeh, 2006). In harvesting stage, management activities can also affect wheat yield. Asghari Meidani (2004) estimated rainfed wheat loss of 9 $\mathrm{kg} \mathrm{ha}^{-1}$ for each harvesting date later than July 25 . He also reported that the use of a Class combine having fingers in the (carousel) led to lower losses compared to a John Deere combine with metallic belts in the carousel. He concluded that harvest losses could be attributed to failure in observing the combine regulations, which was estimated to be $18 \%$, which 
reduced to $6 \%$ with observing relevant regulations resulting in a difference of about $12 \%$. The seeder type also affects yield by changing planting depth, soil compaction rate on the seed, and fertilizer settlement style alongside the seed. According to a three-year research in Hamedan province, a deep cultivator (Kesht Gostar Co.) with a planting depth of $7 \mathrm{~cm}$ had the highest yield compared to other line cultivators and showed a 10\% higher yield than that of manual seeding (Heydari and Firoozabadi, 2008). According to Hemmat and Eskandari (2006), moldboard plowing led to about $20 \%$ less yield compared to shaft plows in autumn, resulting from more spikes per square meter. Lubell et al. (2002) compared the effect of planting date on the yield of wheat cultivars and reported a higher yield of $1550 \mathrm{~kg} \mathrm{ha}^{-1}$ in early October than early and mid-September. Similar research suggests wide differences between farmers in terms of various managements in a small scale (Torabi et al., 2011).

Investigating and determining agronomic factors affecting wheat yield based on reliable statistical methods can be considered as an appropriate tool for introducing the most important factors affecting this crop yield to use and, if necessary, modify agronomic methods and, consequently, increase this crop yield (Sioseh, 2009). Factors limiting yield gap include management and environmental parameters such as tensions and nutrients, and those reducing yield gap include pests, diseases, weeds, and contaminants. Understanding the yield potential and the gap between actual yields of crops and achievable yields is necessary to identify yield-limiting factors.

\section{Materials and methods}

To evaluate agronomic factors affecting crop yield and feasibility of reducing wheat yield gap, a questionnaire was developed in terms of crop management factors affecting yield. To this end, data of most important factors affecting wheat yield were recorded from farmers sampled from different parts of Piranshahr, a southern city in West Azarbaijan province, Iran. All the surveyed farmers were among permanent contractors of wheat cultivar Azar 2 (Oshnavye Khooshe Tala Co.), which is a semiirrigated cultivar cultivated in rainfed conditions as well. Given performing rotation in some plots, information about management factors was obtained from the contractors during six crop seasons, or collected by the researcher. Finally, as data were divided into three years, each management factor was separately analyzed versus the yield. The precise yield of each target plot was determined by obtaining total plot area using a GPS and the loads delivered to the weighbridge of the Khooshe Tala Company by the farmers. Data were analyzed by MSTAT-C and Excel software (Siosemardeh, 2009).

\section{Results and discussion}

Different areas of arable lands had significant effects on wheat yield (Table 1), so that the most areas of land significantly increased the grain yield compared to smaller plots (Figure 1). The relationship between land area and grain yield indicates that at different areas of land $(<1,1-3,3-6,6-10$, and $>10$ hectares), the highest differences were between areas of $0-3$ to and 3-6 hectares. The land area, therefore, plays an important role in yield changes, and lands with larger plots were in a better condition due to more suitable operations of land preparation and cultivation. Siosemardeh et al. (2010) reported that farmers whose plots were larger than five hectares had personal equipment with relatively higher yields than small plots where planting to harvesting operations were done by leased equipment.

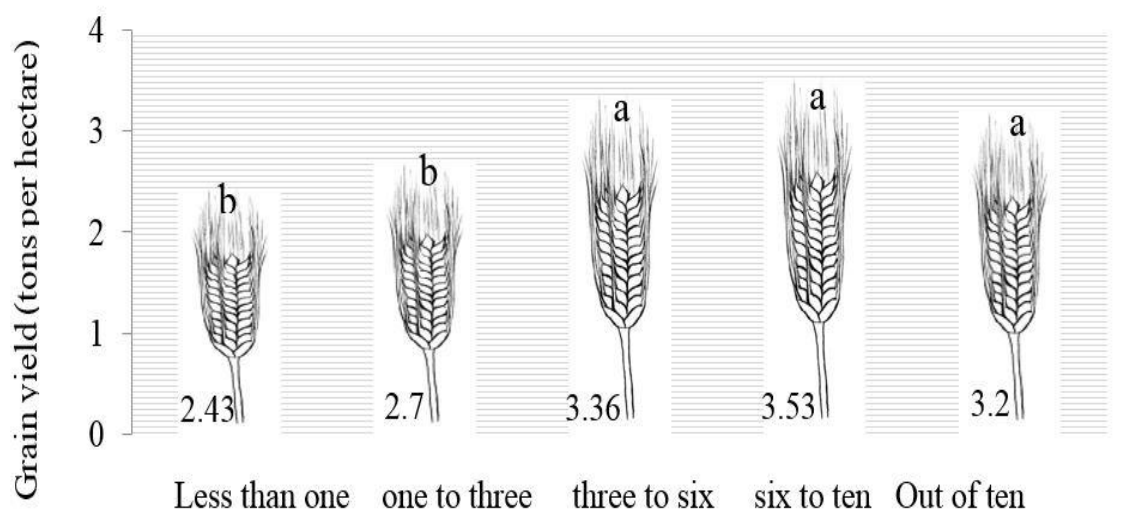

Figure 1. Comparison of mean area of arable land on wheat grain yield.

Different rotations of wheat, pea, and fallow significantly affected grain yield (Table 1). Wheat rotation reduced grain yield compared to pea and fallow rotations. Mean yields of 3.4, 3.3, and 2.4 t/ha were obtained for wheat rotation with fallow, pea, and wheat, respectively (Figure 2). The use of legumes in rotation is a common practice and the effect of using leguminous plants in rainfed rotation is not deniable. This rotation has favorable results and aims at decreasing or totally eliminating fallow land area, an outcome of which is to improve soil nitrogen content (Abdollahi, 2016; Ghaffari, 2002). The benefits of planting such plants as pea with wheat rotation include improved nitrogen uptake, increased grain protein and soil nitrogen, reduced problems of pests, diseases, and weeds, improved soil properties, and elevated availability of nutrients (Williams et al. 2014, Dixon et al., 2006). 


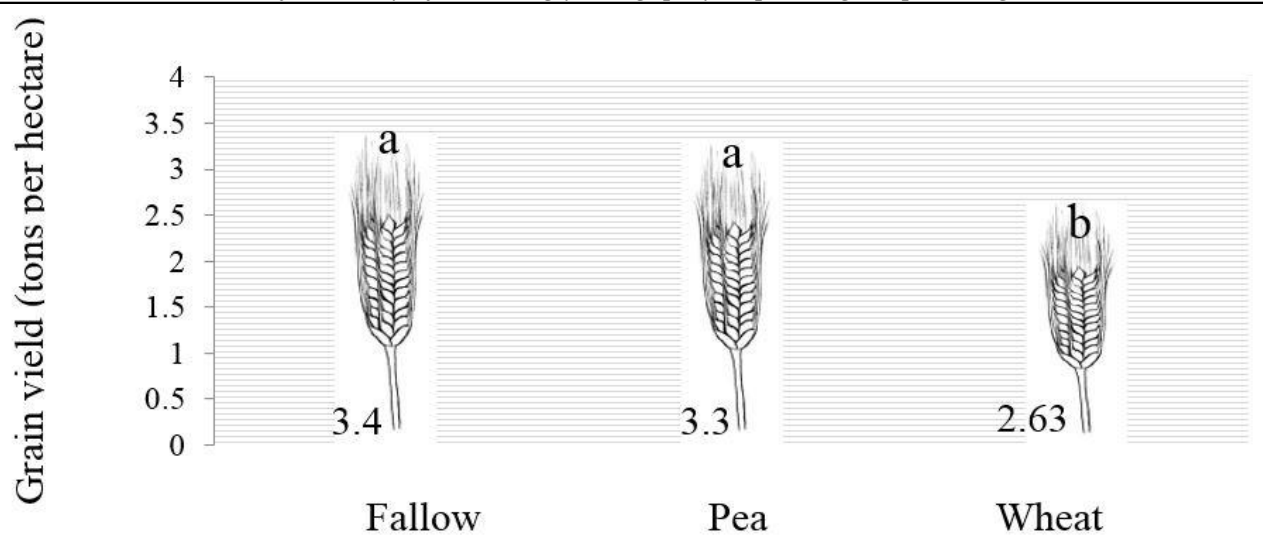

Figure 2. Comparison of the mean of the effects of various alternatives on wheat grain yield.

Soil texture had a significant effect on grain yield (Table 1). Loam and clay soils increased the grain yield significantly compared with stony and sandy soil textures (Figure 3). Lipic et al. (2003) investigated the effect of soil compaction on root growth and crop yields, and provided possible mechanisms between root and aerial organs under compacted soil conditions. Their results showed that crop yield in compacted soil was largely dependent on climatic conditions and the initial soil density. In addition, excessive or very low soil compaction led to changes in root size, abnormal root distribution in the upper part of the soil, and decreased root depth, and as well as dropped water absorption, nutrient uptake, and fertilizer use effects in such soils (Siosemardeh, 2010).
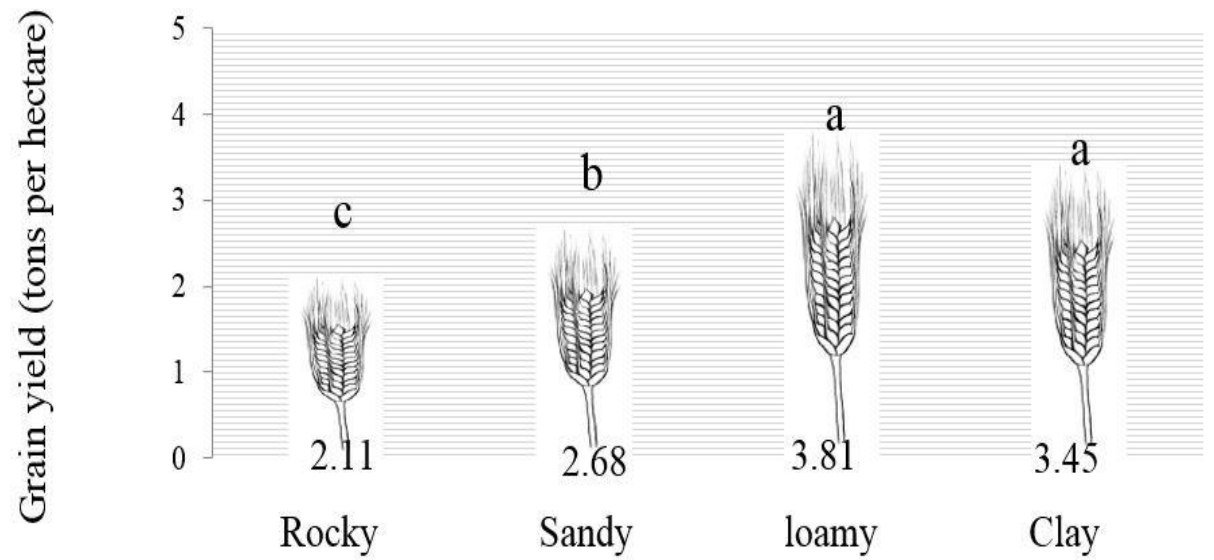

Figure 3. Comparison of the mean of the effects of different soil texture on wheat grain yield.

Plowing date significantly influenced wheat grain yield (Table 1). Plowing in July and August significantly enhanced grain yield in comparison to those in September and October, with lowermost yield observed in October plowing. Plowing in July resulted in a significant increase in yield (Figure 4). The results of this study indicated that plowing in July and August increased soil moisture storage compared to those of September and October, and therefore there will be better yields at these dates. Plowing in July and August reduces water evaporation due to the disruption of capillary tubes in the soil and increases soil moisture storage, resulting in a greater yield in the subsequent crop yield (Siosemardeh, 2009).

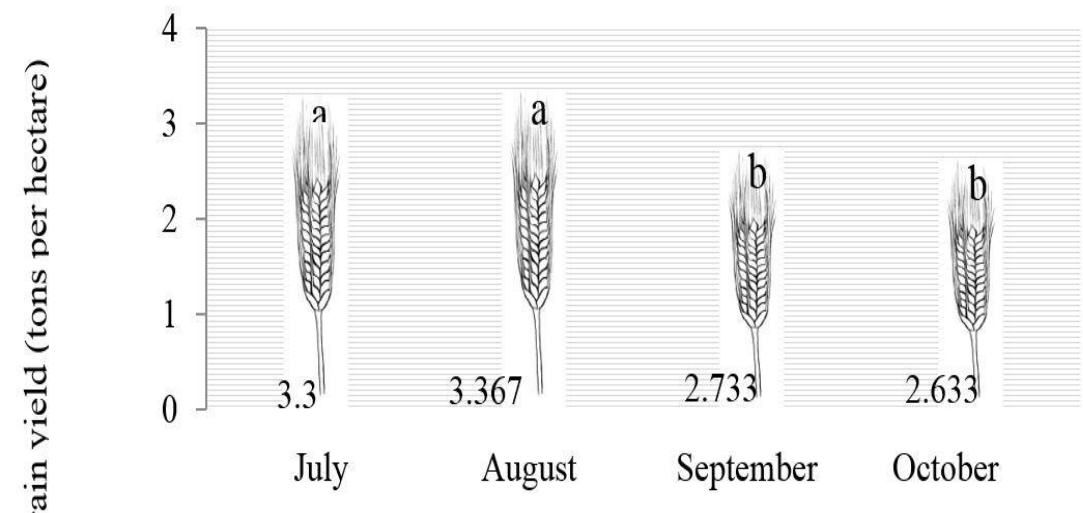

Figure 4. Comparison of the mean of the effect of plowing time on wheat grain yield. 
Significant differences were recorded between the levels of urea fertilizer application on wheat grain yield at $1 \%$ probability level. Increased use of urea fertilizer markedly raised the grain yield. Application of urea fertilizer at levels of 100 and $150 \mathrm{~kg}$ significantly elevated the grain yield compared to fertilizer-free and urea treatment of $50 \mathrm{~kg} / \mathrm{ha}$ (Figure 5). Improved grain yield as a result of urea fertilizer application is due to the fact that plants growing with a sufficient nitrogen supply have a rapid and stable growth. Sufficient nitrogen results in proper chlorophyll content, suitable tillering, normal cell division, and sufficient protein synthesis. Plants use nitrogen since the roots start to function by the time that absorption of all nutrients is ceased (Siosemardeh, 2003). With using $150 \mathrm{~kg} / \mathrm{ha}$ of urea, wheat yield was equivalent to that with less nitrogen consumption per hectare. An mean yield of $3000 \mathrm{~kg} / \mathrm{ha}$ in this study, and assuming a protein content of $12 \%$, with $14 \mathrm{~g}$ of nitrogen per $100 \mathrm{~g}$ of protein (nitrogen comprises $14 \%$ of protein) reflect that $1.68 \%$ of the grain consists of nitrogen. This means that about $19.74 \mathrm{~kg}$ of nitrogen was harvested per hectare by rainfed wheat, equaling $43 \mathrm{~kg} / \mathrm{ha}$ of urea fertilizer use. If urea fertilizer efficiency is considered to be $85 \%, 50 \mathrm{~kg} / \mathrm{ha}$ of nitrogen fertilizer will be needed to compensate for nitrogen consumed per hectare of rainfed wheat due to grain nitrogen uptake (Rastgar, 2004).

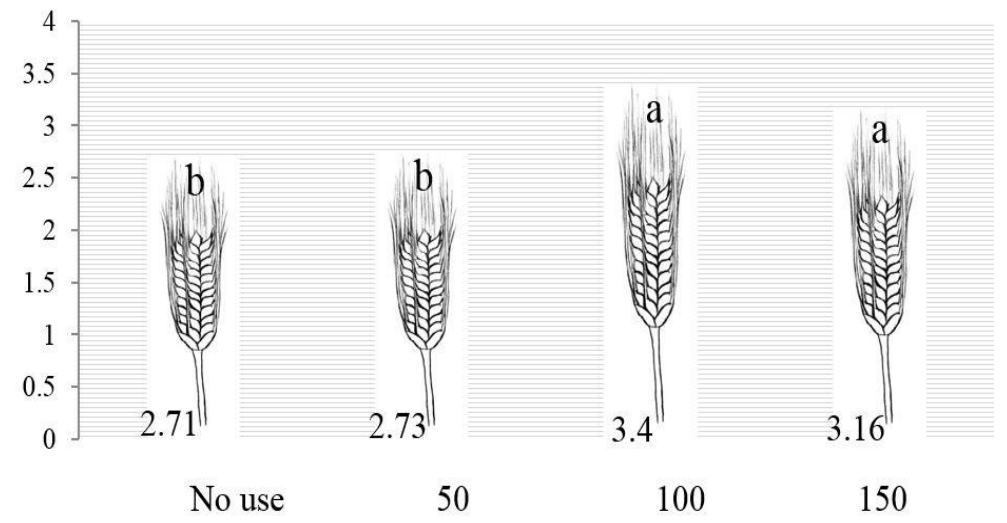

Figure 5. Comparison of the mean of the effect of the amount of urea on wheat grain yield.

The treatments for urea usage dates were significantly different in terms of grain yield (Table 1). The effects of urea fertilizer application on wheat grain yield in spring and autumn were greater than that of spring. A comparison of mean data (Figure 6) revealed that grain yields in autumn fertilizer use and urea fertilizer uses in autumn and spring were significantly higher than those of spring consumption. In other words, to improve yield in rainfed conditions, nitrogen fertilizer application in autumn is necessary to complete the period necessary for wintering. Nitrogen fertilizer can be completely used in autumn or one part be used in autumn and the other in spring, and its one-time application in spring will not be desirable. The cold weather and high rainfall in April reduced the effects of consumed top-dress fertilizer (Figure 6); therefore, it probably has a limiting effect on cold-spring years (Sioseh Mardeh et al., 2010; Rastgar, 2004).

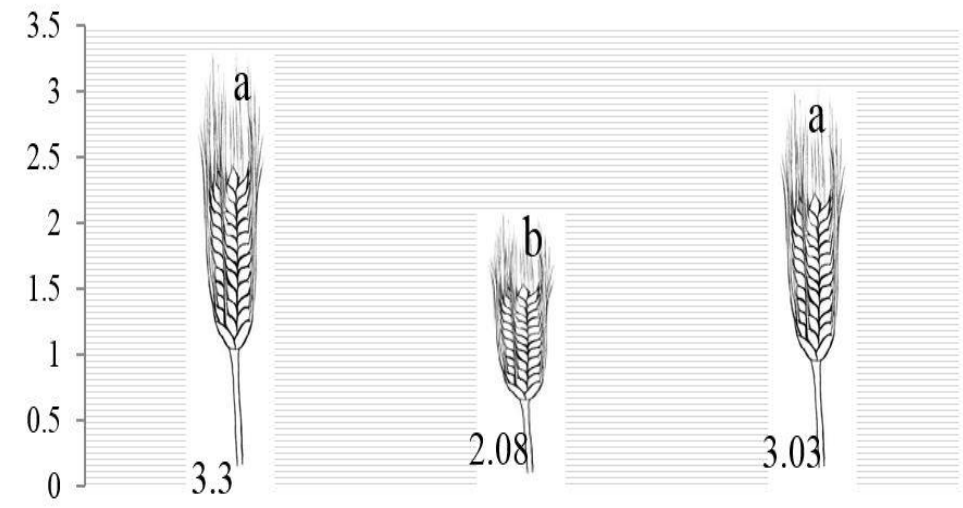

Autumn and spring spring autumn

Figure 6. Comparison of the mean time of use of urea on wheat grain yield.

Application of phosphate fertilizer affected wheat grain yield at $1 \%$ significance level (Table 2). Our observations showed that, with increasing phosphorus consumption up to $100 \mathrm{~kg} / \mathrm{ha}$, the grain yield was increased but it was decreased with further use of phosphorus (Figure 7). Comparison of mean values (Figure 10) indicated that wheat yield was uppermost (3.7 t/ha) with phosphorus consumption of $100 \mathrm{~kg} / \mathrm{ha}$, and the treatments with $50 \mathrm{~kg}$ and no use of phosphate fertilizer had the lowest yields. The use of chemical fertilizers in crop farming can have a major impact on the yield. According to reports, consumption of $30 \mathrm{~kg} \mathrm{P} / \mathrm{ha}$ led to the highest yield of rainfed wheat (Najmoddini and Shahooie, 2008). According to Farajnia et al. (2008), however, the amount of phosphorus in soil surface layer $(0-30 \mathrm{~cm})$ was more than allowed limits in more than $78 \%$ of the lands (of totally 400 samples) sampled in Maragheh. 


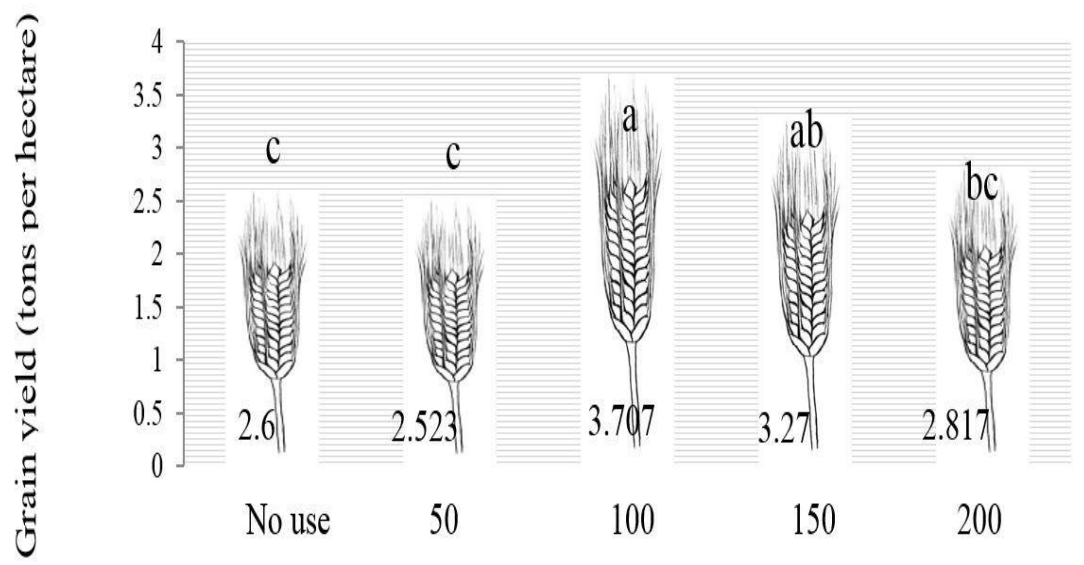

Figure 7. Comparison of the amount of phosphate fertilizer on wheat grain yield.

Potash fertilizer had a significant effect on wheat grain yield at $1 \%$ significance level (Table 2). Comparison of mean values indicated increased yield with rising potassium consumption, and the highest yield was observed in potash treatment of 100 $\mathrm{kg} / \mathrm{ha}$ (Figure 8). The key roles of potassium in increasing photosynthesis rate, carbon dioxide absorption, and facilitating carbon transfer process from sources to reservoirs (Sangakkara et al., 2000) result in the elevated grain yield. Potassium plays a major role in most processes involving enzymatic activities, photosynthesis, sugar transfer, protein synthesis, starch, better plant establishment under moisture stress conditions by adjusting the rate of stomatal opening and closing, improving resistance to lodging, pest infestation, and diseases (Hoeft et al., 2000), thereby exerting a direct effect on the produced grain yield. Potash fertilizer application together with nitrogen and phosphorous had significant effects on sesame seed yield components and finally increased sesame grain yield and oil (Sharma et al. 2005). Also, application of potash fertilizer (250 kg) increased grain yield, seed number in pods, 1000-grain weight, and harvest index in rapeseed and Indian mustard (Fnayy et al., 2009; Fanaei et al., 2009).

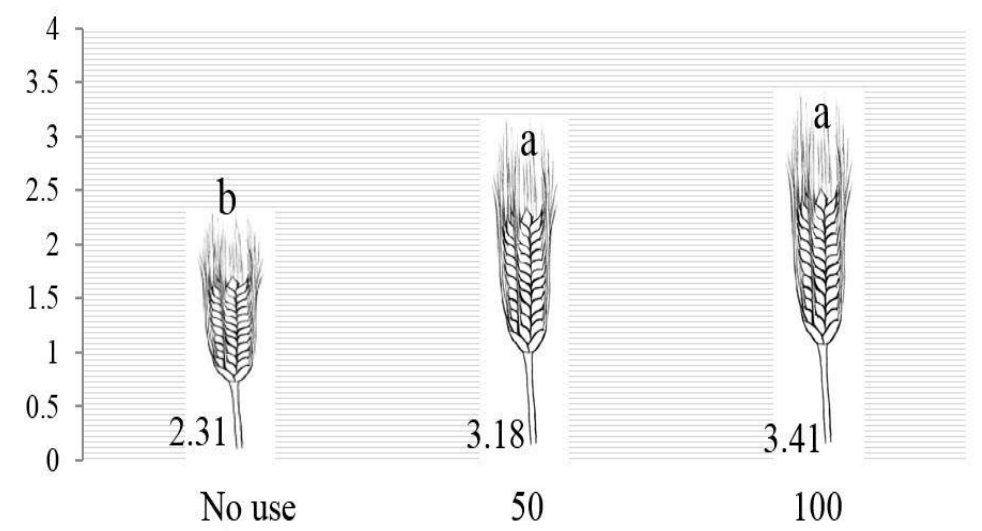

Figure 8. Comparison of the mean of potassium fertilizer on wheat grain yield.

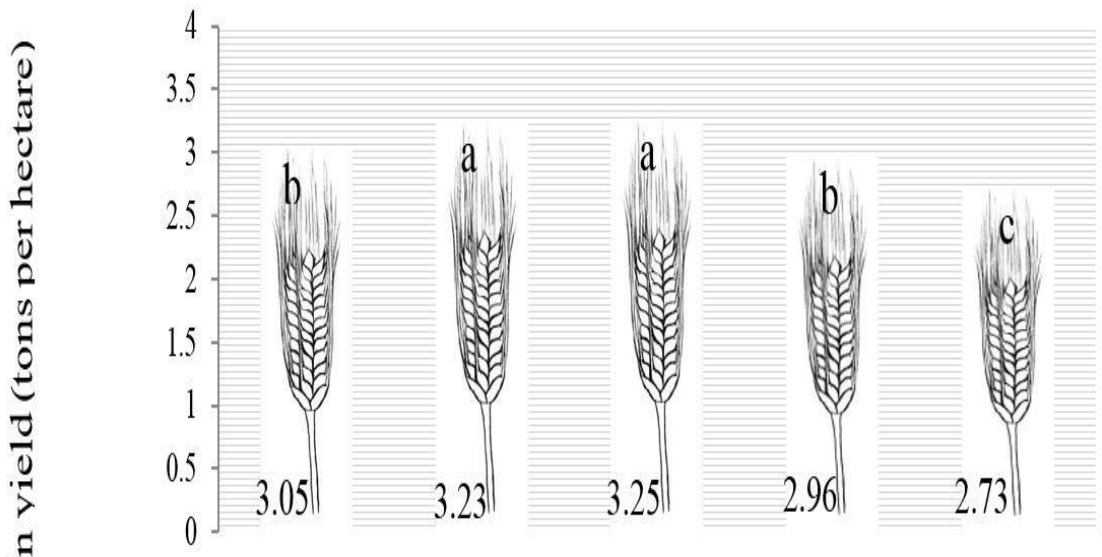

Second half September - first half October - second half October - first half November - second half

Figure 9. Comparison of the mean of the effect of different planting times on wheat grain yield. 
The ANOVA results (Table 2) for the effects of different planting dates on grain yield shows significant yield differences between the treatments. Comparison of the mean grain yields showed that the highest yield belonged to the treatments cultivated during the first and the second half of October. In this experiment, grain yield decreased about 8.4 and $18.3 \%$ in plantings of the first and the second half of November compared to those in the first and the second half of October, respectively. The yield was decreased significantly with delayed cultivation. The highest grain yield ( 3.25 ton/ha) belonged to the cultivation date in the second half of October and the lowest $(2.73 \mathrm{t} / \mathrm{ha})$ was related to that in the second half of November (Figure 9). It seems that delayed cultivation exposes the grain filling stage to high temperatures and reduces its period duration and probably the grain filling rate, leading to reductions in 1000-grain weight and thus the grain yield. A suitable planting date brings about optimal use of climatic factors such as temperature, humidity, and daytime, and is an important factor influencing the durations of vegetative and reproductive growth and a balance between the two (Radmehr et al., 2005). In delayed wheat cultivation, plants need to complete their life cycles in a short time period, and the accumulation of starch finishes early in the plants cultivated with delay compared to those planted on time (Khan et al., 2010). Delayed cultivation results in poor tillering and delayed germination due to the predominance of low temperatures at this stage, thereby, weak crop establishment affects grain yield. On the other hand, high temperatures at final stages of growth shorten the grain filling period and early ripening (Sattar et al., 2007; Subedi et al., 2010). Farmers of the province usually cultivate rainfed wheat in October and November before the beginning of precipitation season. Planting in October was associated with the highest yield. Cultivation in September was associated with reduced yield probably due to excessive drying of seeds in contact with the soil, or consumption of seeds by soil organisms and reducing the disinfectant effects of seed disinfection poison up to the time of rainfall and germination. Also, planting later than October is often resulted in cultivation after the first rainfall and crop growth reduced due to no use of the first rainfall; hence, wheat did not use the entire growth period leading to dropped yields (Wysocki and Cro, 2006).

Also, Ganbari et al. (2012) presented evidence that the first planting date (October 10) with a mean yield of 4,616 kg ha ${ }^{-1}$ had the highest yield and the fourth planting date (November 10) with $2,197 \mathrm{~kg} \mathrm{ha}^{-1}$ led to the lowest yield. Hongyong et al. (2007) conducted a study in China during 2003-2005 and concluded that wheat germinated in 7 days in the usual planting date, but the days required for wheat germination increased to 13 days after delayed planting, along with decreased temperatures required to complete the growth stages. Flowers et al. (2006) investigated the effect of planting date on yield and yield components of two wheat cultivars and reported that planting date had a significant effect on wheat yield, and that delayed planting date reduced wheat yield by $24 \%$. They also stated that planting date significantly affected grain yield under rainy conditions. Fathi et al. (2001) observed a decline in the grain yield of durum wheat (Dena cultivar) with delayed planting from 15th of October to 15th of November.
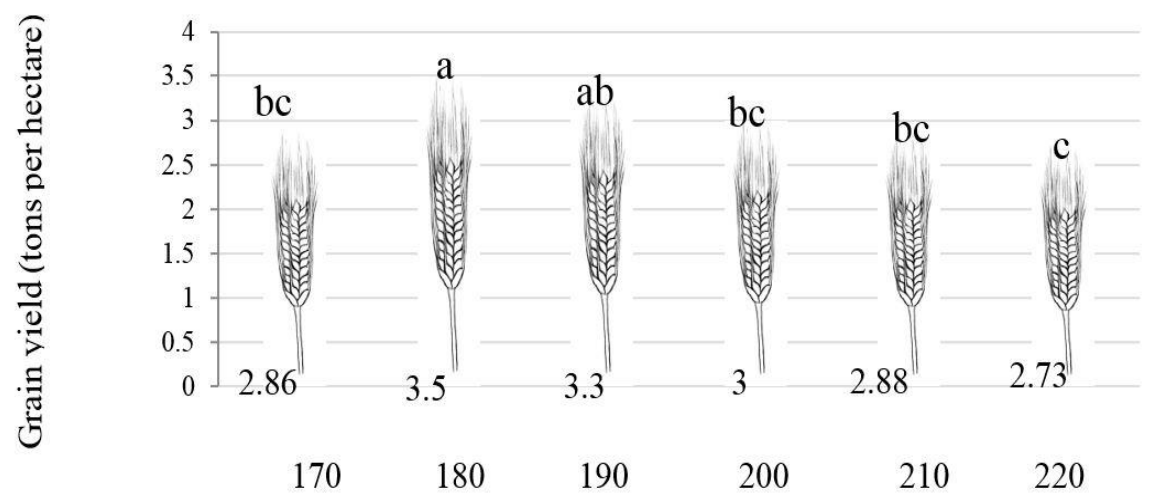

Figure 10. Comparison of the mean of the effect of different amounts of seed on wheat grain yield.

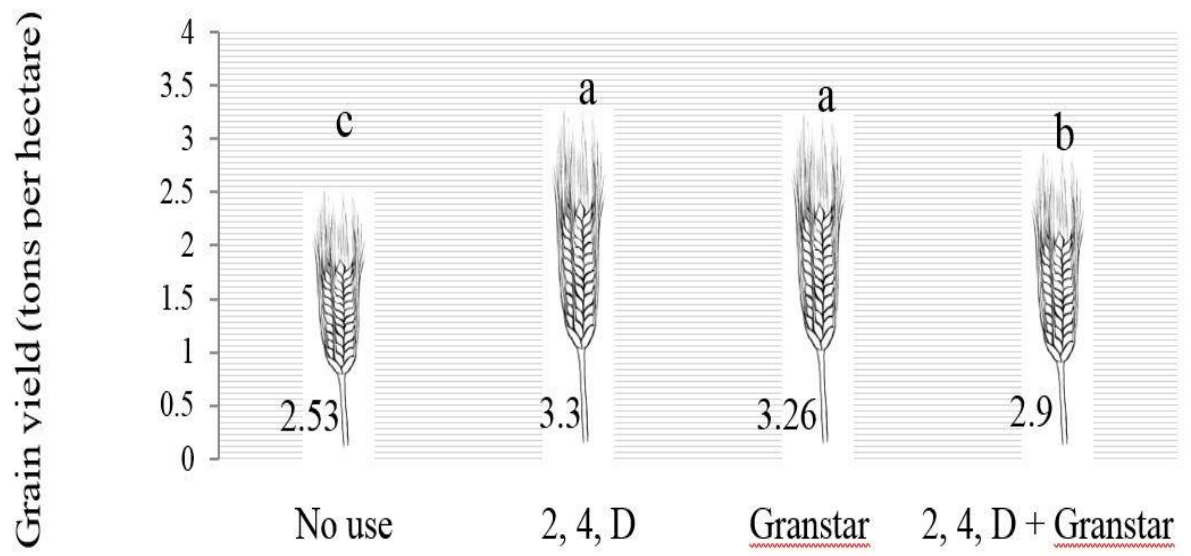

Figure 11. Comparison of the mean of the herbicide on wheat grain yield.

According to ANOVA results, different seed consumption levels showed statistically significant effects on wheat grain yield per unit area at $1 \%$ level (Table 2). Comparison of mean data revealed that seed consumption of $180 \mathrm{~g} /$ ha resulted in the highest yield, and treatments with 170,190,200,210, $220 \mathrm{~kg} / \mathrm{ha}$ of seed consumption had similar effects on wheat yield (Fig. 10). If all 
necessary conditions (e.g., suitable cultivar, fertilizer, etc.) are available, but the plant density is not appropriate, maximum yield per unit area will not be achieved (Asdollahzadeh et al., 2010). Optimal seed consumption reduces seed costs and crop lodging, and improves plant status against herbal diseases (Mazaheri and Majnon Hosseini, 2008). Hiltbrunner et al. (2007) suggest optimum planting densities in wheat to be the key to maximizing yield. As reported by Omidinasab et al. (2016), less seed consumption per hectare did not reduce grain yield. According to the overall results of this experiment, it seems that less seed consumption per hectare did not lower grain yield. Therefore, optimum grain yield, while saving seed consumption, can be achieved with optimum seed use, which varies according to the regional soil and climatic conditions.

The effect of applied herbicide type on wheat grain yield was significant at $1 \%$ level (Table 3). Figure 11 shows that the use of 2, 4-D and Granstar herbicides alone led to higher yields than the treatments with using mixed herbicides and no herbicide application. This could have resulted from dropped weed density in this treatment, which reduced weed competition with wheat and resulted in higher wheat yields than their combined application. Many experiments demonstrated that herbicides play a significant role in reducing weed density and dry weight and, consequently, increasing crop yields (Norsworthy and Fredrick, 2005). Wheat yield reportedly increased by $44 \%$ with using 2, 4-D herbicide versus no use treatment (Mohammad Doost Chamanadad et al. 2011).

The effect of pesticide application was significant on seed yield at $1 \%$ level (Table 3). Considering the significant effect of pesticide use, total grain yield with pesticide use of $1.5 \mathrm{~L} / \mathrm{ha}$ was $18 \%$ lesser than those with consumptions of 0.5 and $1.5 \mathrm{~L} / \mathrm{ha}$ (Figure 12). The results indicated that increased use of pesticides in the field led to yield gain regarding both pesticide diversity and the quantity of active ingredients (Bazrgar et al., 2013).

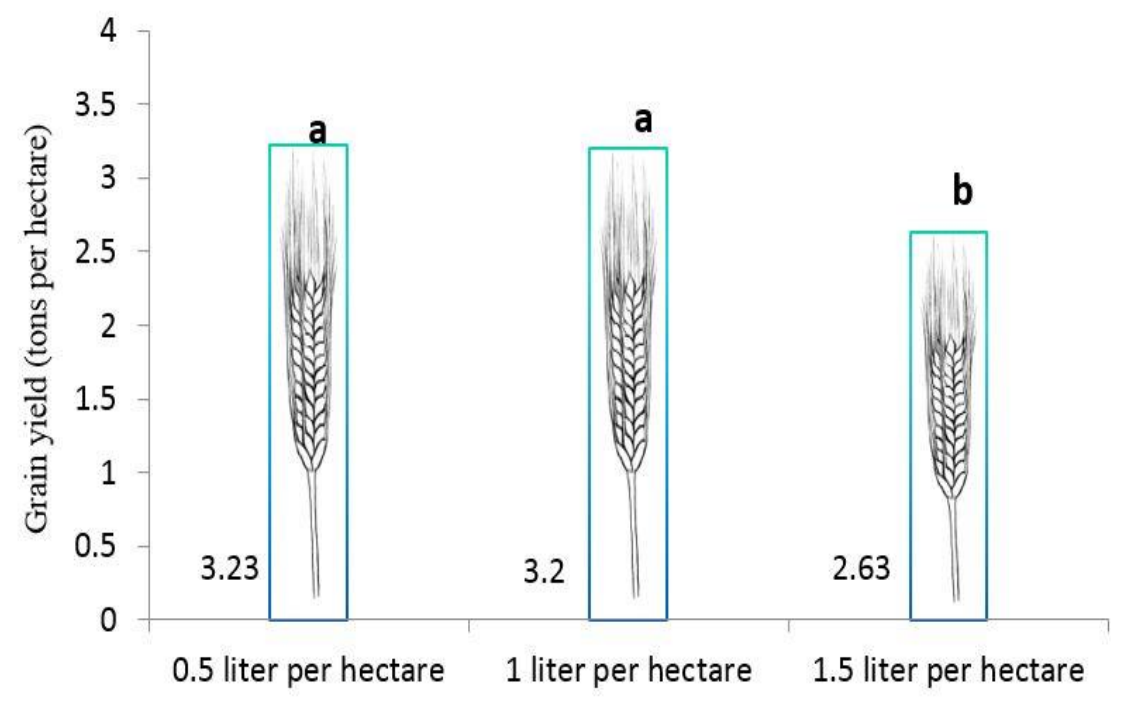

Figure 12. Comparison of the mean of the amount of pesticide on wheat grain yield.

ANOVA determined that the effect of harvest date was significant (1\%) on grain yield (Table 3). Considering the significant effect of harvest time on grain yield (Figure 13), there were significant differences between harvest times and grain yields. Harvest time in July 5-10 led to the lowest yield and those in July 15-20 and 20-25 resulted in the highest grain yields. Management activities can affect wheat yield in harvesting stage as well. A rainfed wheat loss of $9 \mathrm{~kg} / \mathrm{ha}$ was estimated for each harvest date later than July 25th (Asghari Meidani 2004).

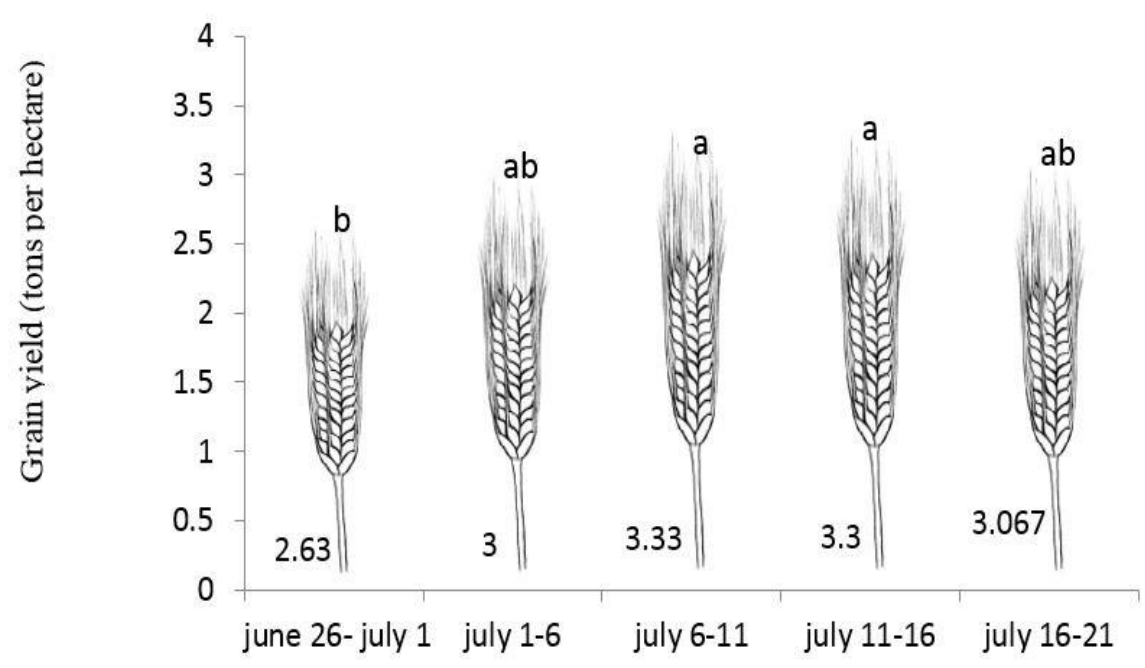

Figure 13. Comparison of the mean of the harvest date on wheat grain yield. 
The type of employed combine significantly influenced the grain yield at a level of 1\% (Table 3). The results showed that the use of K130 and Hyundai combine harvesters led to greater yields than using John Deere i1055 and 955 combines (Figure 14). An important part of total wheat production loss in the country occurs during harvesting with combine, with figures of 4.1818.1 percent mentioned in the literature (Anon, 2003). Asghari Meidani (2004) reported that increasing the forward speed of combine from 0.9 to $2.4 \mathrm{~km} / \mathrm{h}$ led to no significant elevations in the crop loss, but rising forward speed to $3.2 \mathrm{~km} / \mathrm{h}$ significantly amplified grain losses and yield reductions. Application of worn-out combines with no specific regulations can be associated with grain fall and reduced amount of harvested wheat. Asghari Meidani (2004) reported that losses in harvesting were mostly due to non-observance of the combine regulations calculated to be $18 \%$, which fell to $6 \%$ with observing the relevant settings, yielding about $12 \%$ difference between the two percentages. If the problem is resolved, an increased production of 55,000 tones can be obtained at the land areas.

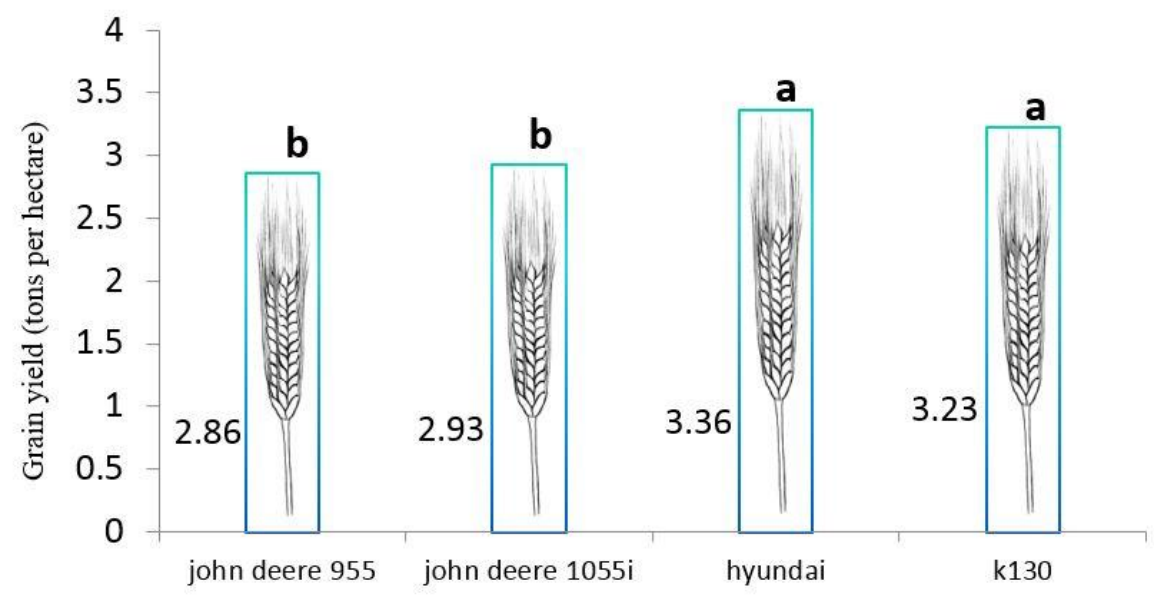

Figure 14. Comparison of the mean of the combine type on wheat grain yield.

Table 1. Analysis of variance of the effect of traits of agricultural land levels, geographic location, different alternatives, soil texture and type of plow on wheat grain yield.

\begin{tabular}{lllllll}
\hline Mean of squares & & & & d.f & Source of variation \\
\hline Time to use urea & Plowing time & soil pattern & Different Rotations & Agricultural land levels & & \\
$0 / 268$ & $0 / 361$ & $0 / 003$ & $0 / 174$ & $0 / 625$ & 2 & Repeat \\
${ }^{* *} 0 / 188$ & ${ }^{* *} 0 / 430$ & ${ }^{* *} 1 / 810$ & ${ }^{* *} 0 / 444$ & ${ }^{* *} 0 / 644$ & 4 & Treatment \\
$0 / 018$ & $0 / 033$ & $0 / 103$ & $0 / 049$ & $0 / 069$ & 8 & Error \\
$4 / 38$ & $6 / 04$ & $11 / 64$ & 43668 & $9 / 91$ & Coefficient of variant
\end{tabular}

* And ** There is a significant difference between them at the probability level of 5\% and 1\%, respectively

Table 2. Analysis of variance effect of traits, plowing time, time of urea use and amount of urea use, phosphate fertilizer application and potassium fertilizer on wheat grain yield.

\begin{tabular}{|c|c|c|c|c|c|c|c|}
\hline \multicolumn{6}{|c|}{ Mean of squares } & \multirow[t]{2}{*}{ d.f } & \multirow{2}{*}{$\begin{array}{l}\text { Source of } \\
\text { variation }\end{array}$} \\
\hline $\begin{array}{l}\text { Different } \\
\text { times }\end{array}$ & planting & $\begin{array}{l}\text { Seed } \\
\text { consumption }\end{array}$ & $\begin{array}{l}\text { potassium } \\
\text { fertilizer }\end{array}$ & $\begin{array}{l}\text { phosphate } \\
\text { fertilizer }\end{array}$ & $\begin{array}{l}\text { The amount of } \\
\text { urea used }\end{array}$ & & \\
\hline $2 / 513$ & & $2 / 082$ & $0 / 311$ & $0 / 350$ & $0 / 275$ & 2 & Repeat \\
\hline${ }^{* *} 0 / 132$ & & ${ }^{* *} 0 / 261$ & ${ }^{* *} 1 / 055$ & ${ }^{* *} 0 / 744$ & ${ }^{* *} 0 / 243$ & 4 & Treatment \\
\hline 0/010 & & 0/058 & $0 / 028$ & 0/064 & 0/032 & 8 & Error \\
\hline $6 / 04$ & & $11 / 64$ & $5 / 64$ & $8 / 46$ & $5 / 94$ & \multicolumn{2}{|c|}{ Coefficient of variant } \\
\hline
\end{tabular}

*And ** There is a significant difference between them at the probability level of $5 \%$ and $1 \%$, respectively

Table 3. Analysis of variance of the effects of herbicide type, rate of using herbicides, rate of using pesticide, SPAD, time of harvesting and type of combine on wheat grain yield.

\begin{tabular}{|c|c|c|c|c|c|}
\hline \multicolumn{4}{|l|}{ Mean of squares } & \multirow[t]{2}{*}{ d.f } & \multirow{2}{*}{$\begin{array}{l}\text { Source of } \\
\text { variation }\end{array}$} \\
\hline Type of combine & Time of harvest & Dose of use pesticide & Type of herbicide & & \\
\hline $2 / 058$ & $2 / 819$ & $1 / 781$ & $1 / 373$ & 2 & Repeat \\
\hline$\star * 0 / 171$ & $* * 0 / 238$ & $* * 0 / 341$ & $* * 0 / 389$ & 4 & Treatment \\
\hline 0/009 & 0/058 & $0 / 018$ & $0 / 011$ & 8 & Error \\
\hline 2/99 & $7 / 84$ & $4 / 41$ & $3 / 56$ & \multicolumn{2}{|c|}{ Coefficient of variant } \\
\hline
\end{tabular}

\footnotetext{
* And ** There is a significant difference between them at the probability level of $5 \%$ and $1 \%$, respectively
} 


\section{Conclusion}

Comparisons on the impact of each examined management on obtainable yield in the region revealed that crop land characteristics including land area and soil texture had an impact of $28 \%$ on the grain yield. In addition, managements for planting (planting date, seed consumption, rotation, plowing date, application date of urea fertilizer, and NPK fertilizer application levels), growing (herbicide type and pesticide doses), and harvesting (harvest date and combine type) with 29, 23 , and $20 \%$, respectively, effectively determined wheat grain yield.

\section{References}

Abdullahi, A. (2016). Effect of Different Agronomic Alternatives on Grain Yield and Some Agronomic Characteristics of Wheat (Triticum aestivum L.) in Dryland Conditions of Kermanshah. Journal of Agricultural Ecology, 8(3), 384-373.

Ahmadi, L. M., \& Emam, Y. (2013). Response of wheat genotypes to terminal drought stress using physiological indices. Journal of Crop Production and Proccesing, 3(9), 163-176.

Ahmadi, H., and Jafarzadeh, M. (2006). Competitive power evaluation of wheat cultivars with weeds in Kurdistan province. The first conference of research findings in agriculture and natural resources in Kurdistan province. Sanandaj.

Arabian, A., Kalantari, Kh., Asadi, A., and Shaban, A. F. H. (2009). Evaluation of Stability Level of Wheat System in Fars Province and Determining the Factors Affecting it. Iranian Journal of Agricultural Extension and Education, 2, 17-28.

Asdollahzadeh, R., Naderi, A., \& Kakzadeh, A. (2010). Effect of plant density on yield and yield components of wheat genotypes in different planting patterns. Quarterly Journal of Crop Physiology, 2(1), 4-6.

Awadhwal, N. K., \& Thierstein, G. E. (1985). Soil crust and its impact on crop establishment: a review. Soil and Tillage Research, 5(3), 289-302.

Azimzadeh, M., Koocheki, A., and Bala, M. (2002). Effect of different plowing methods on bulk density, porosity, soil moisture and wheat yield in rainfed conditions. Journal of Agricultural Sciences of Iran, 4(3), 209-224.

Bellido, L. L., Fuentes, M., Castillo, J. E., Lopes, F. J., and Fernandez, E. J. (1996). Long term tillage, crop rotation and nitrogen effect on wheat yield under rainfed meditranean condition. Agron J, 88, 783-791.

Dixon, J., Nally, L., Aquino, P., Kosina, P., la Rovere, R., and Hellin, J. (2006). Centenary review: Adoption and economic impact of improved wheat varieties in developing countries. Journal of Agricultural Science, 144, 489-502.

Lipiec, J., Medvedev, V. V., Birkas, M., Dumitru, E., Lyndina, T. E., and Rousseva, S. (2003). Effect of soil compaction on root growth and crop yield in Central and Eastern Europe. Int Agrophysics, 17, 61-69.

Fanaei, H. R., Galavi, M., Kafi, M., and Ghanbari, B. A. (2009). Amelioration of water stress by potassium fertilizer in two oilseed species. International Journal of Plant Production, 3(2), 41-54.

Farajnia, A., Baiboardi, A., and Kalantari, A. (2008). Application of GIS in preparation of soil pollution map of Maragheh to P. The 2nd Regional Conference of Agricultural and Natural Resources (West of the country). Sanandaj.

Fateh, H. (2010). Effect of nitrogen and zinc fertilizers under drought stress conditions on physiological characteristics of two barley varieties (Hordeum vulgare) in autumn. Master's Thesis. The University of Kordestan.

Fathi, G., Siadat, S. A., Rossbe, N., Abdali-Mashhadi, A. R., \& Ebrahimpoor, F. (2001). Effect of planting date and seed density on yield components and grain yield of wheat cV. Dena in Yassoj conditions. Journal of Agriculture Science and Natural Resources, 8(3), 23-31.

Flowers, M., James, C., Petrie, S., Machado, S., and Rhinhart, K. (2006). Planting date and seeding rate effects on the yield of winter and spring wheat varieties results from the 2005-2006 cropping year. Agri Res, 12(2), 72-74.

Fnayy, H. R., Geloy, M., Kafy, M., Bnjar, G. A., and Shirani, R. A. H. (2009). Effect of potassium fertilizer and irrigation on grain yield and water use efficiency in two varieties of rapeseed (Brassica napus L.) and Indian mustard (Brassica juncea L.). Journal of Agricultural Science, 11(3), 289-271.

Ghaffari, A. (2002). Study on rotation of wheat (Sardari cultivar) with sunflower, chickpea and fallow under dryland conditions. Plant and Seed, 18, 130-143.

Ghanbari, A., Roshani, A., and Tavassoli, A. (2012). The Effect of Sowing Date on Some Agronomic Characteristics and Grain Yield of Winter Wheat Cultivars. Scientific Journal of Ecophysiology of Crop Plants, 6(22), 127-144.

Hemmat, A., and Eskandari, I. (2006). Dry land winter wheat response to conservation tillage in a continuous cropping system in northwestern Iran. Soil and Tillage research, 86, 99-109.

Hiltbrunner, J., Streit, B., and Lidgens, M. (2007). Are seeding densities an opportunity to increase grain yield of winter wheat in a mulch of white clover? Field Crops Research, 102, 163-171.

Hoeft, R. G., Nafziger, E. D., Johnson, R. R., and Aldrich, R. (2000). Modern Corn and Soybean Production, MCSP Publications, USA.

Hongyong, S., Zhang, X., Chen, S., Pei, D., and Liu, C. (2007). Effect of harvest and sowing time on the performance of the rotation of winter wheat-summer maize in the North China Plain. Industrial Crops and Products, 25, 239-247.

Khan, M. B., Gurchani, M., Hussain, M., and Mahmood, K. (2010). Wheat seed invigoration by pre-sowing chilling treatments. Pak J Bot, 42, 1561-1566.

Kinaci, G., and Kinaci, E. (2005). Effect of zinc application on quality traits of barley in semi-arid zones of Turkey. Plant Soils Environment, 51(7), 328-334.

Maqsood, A., Rahmatulla, M., Kanwal, Sh., Aziz, T., and Ashraf, M. (2009). Evaluation of zn distribution among grain straw of twelve indigenous wheat (Triticum aestivum) genotypes. Pakistan Journal of Botany, 41(1), 225-231.

Mazaheri, D., and Majnon, H. N. (2008). General agriculture (6th edn). Tehran University Press. 
Mir-Vakili, M., and Baghestani, M. A. (2005). Effect of integrate of 2, 4-D and Clodinafop propagile in wheat fields of Yazd province. Proceeding of the 2nd Iranian Weed Sci Cong, pp: 457-461.

Mohammad, D. C. H. R., Pourmourad, K. B., and Asghari, A. (2011). The Effect of Usage of Urea and Herbicide on Wheat Density, Arrangement of Weeds and Winter Wheat yield. Journal of Plant Protection (Agriculture Sciences and Technology), 25(2), 145-151.

Nabati, A., and Sharifi, P. (2016). Yield and yield components of three wheat genotypes under irrigation regimes. Scientific Journal of Ecophysiology of Agricultural Plants, 10, 1(37), 183-200.

Najmoddini, N., and Shahoei, S. (2008). Effect of soil erosion on decreasing the production capacity of rainfed wheat in Kordestan. The 2nd Regional Conference of Agricultural and Natural Resources (West of the country). Sanandaj.

Norsworthy, J. K., and Fredrick, J. R. (2005). Integrated weed management strategies for maize production on the southeastern coastal of North America. Crop Protec, 24, 119-126.

Omidi, N. D., Gareneh, M. H., Bakhshandeh, A. M., Sharafi, Z. M., and Shafi, N. A. (2016). Evaluation of yield and yield components of wheat in response to reduction of nitrogen fertilizer and seed consumption under sustainable agricultural conditions. Journal of Crop Research, 6(1), 89-103.

Radmehr, M., Ayeneh, Gh. A., and Mamaghani, R. (2005). Response of late, medium and early maturity bread wheat cultivars to different sowing dates. 1: Effect of sowing date on phonological, morphological and grain yield of four bread wheat cultivars. J Plant and Seed, 21, 175-189.

Ransak, M. W., Frye, W., Ditsch, D. C., and Blevins, R. L. (1986). Soil erosion with different tillage and cropping system. Soil Science news and Vieews, Dep. Agron. University of Kentucky, Lexington.

Rastgar, M. A. (1992). Dryfarming. Tehran University Press, Tehran, Iran.

Sadri, M. H., Mansour, G. M., Tosheh, V., Bostani, M. K., and Shariati, A. (2004). Study of co-spraying of some micronutrient fertilizers and pesticide pesticides on quantitative and qualitative properties of rainfed wheat. Eighth Congress of Agronomy and Plant Breeding. Rasht.

Sangakkara, U. R., Frehner, M., and Nösberger, J. (2000). Effect of soil moisture and potassium fertilizer on shoot water potential, photosynthesis and partitioning of carbon in mungbean and cowpea. Journal of Agronomy and Crop Science, 185, 201-207.

Sattar, A., Cheema, M. A., Farooq, M., Wahid, M. A., Wahid, A., and Babar, B. H. (2010). Evaluating the performance of wheat varieties under late sown conditions. Int J Agric Biol, 12, 561-565.

Shahoei, S., Mohamadi, J., and Abdolmaleki, P. (1989). Tillage and crop management in dryland farming regions of Iran. International workshop of soil and crop management, Ankara, Turkey.

Sharghi, T., Sedighi, H. and Roknoddin, E. A. (2010). Effective factors in achieving sustainable agriculture. American Journal of Agricultural and Biological Sciences, 5, 235-241.

Sharma, P. B. (2005). Fertilizer management in sesame (Sesamun indicum L.) based intercropping system in Tawa command area. Journal of Oilseeds Research, 22, 63-65.

Siosemardeh, A. (2003). Study of physiological aspects of drought resistance in wheat cultivars. Doctoral dissertation, University of Tehran.

Siosemardeh, A. (2009). Evaluation of factors affecting wheat farming in Kurdistan province. Research project of Agricultural Research Center of Kurdistan Province.

Soleimani, F. A., Naseri, R., and Mirzaeei, A. (2011). Effect of drought stress on yield and yield components of three wheat cultivars in Varamin region. 2th Agriculture and Sustainable Development, Islamic Azad University, Shiraz Branch, Iran. Subedi, K. D., Ma, B. L., and Xue, A. G. (2007). Planting date and nitrogen effects on grain yield and protein content of spring wheat. Crop Sci, 47, 36-44.

Torabi, B., Soltani, A., Galeshi, S., and Zeinali, E. (2012). Analyzing wheat yield constraints in Gorgan. Elect J Crop Prod, 4, 1-17. Williams, C. M., King, J. R., Ross, S. M., Olson, M. A., Hoy, C. F., and Lopetionsky, K. J. (2014). Effects of three pulse crops on subsequent barley, canola, and wheat. Agronomy Journal, 106, 343-350.

Wysocki, D., and Cro, M. (2006). Using seed size, planting date, and expected yield to adjust dryland winter wheat seeding rates. Oregon Agricultural Experiment Station Special Report 1068.

Yang, J., Zhang, J., Huang, Z., Zhu, Q., and Wang, L. (2000). Remobilization of carbon reserves is improved by controlled soil drying during seed filling of wheat. Crop Science, 40, 1645-1655.

Ziaean, A. (2003). Use of Microelements in agriculture. Agricultural Education Publishing.

Citation: Abderrahim, A., Zahr-Eddine, D., Fethi, A., Abdelmadjid, B. (2019). The feasibility of reducing yield gap by improving crop management. Ukrainian Journal of Ecology, 9(3), 21-30.

(cc) $\mathrm{EY}$ This work is licensed under a Creative Commons Attribution 4.0. License 